\title{
Berbagi Surga: Poligami di Indonesia Dalam Bingkai Media Asing
}

\section{(Sharing Heaven: Polygamy in Indonesia on Foreign Media frames)}

\author{
Fakhrur Rozi $^{1 \bowtie}$, Firda Adinda Syukri ${ }^{2}$ \\ 1,2 Program Studi Ilmu Komunikasi, Universitas Islam Negeri (UIN) Sumatera Utara, Indonesia \\ email: fakhrurrozi@uinsu.ac.id
}

$\begin{array}{ccc}\text { First received: } & \text { Revised: } & \text { Final Accepted: } \\ 2 \text { May } 2020 & 16 \text { May } 2020 & 30 \text { May 2020 }\end{array}$

\begin{abstract}
The purpose of this research is to find out how to pack polygamy issue in the video Polemik. Poligami di Indonesia: Berbagi Surga in Vice Indonesia Youtube Channel with Zhongdang and M. Kosicki model framing analysis through syntaksis device, script device, tematic device, and retoris device which is highlighted in the frame of the video story. The methodology of this study used qualitative approach with data collection through documentation on the video, the data obtained and then analyzed through the framing structure model Zhongdang and M. Kosicki. As the results showed that Vice Indonesia framed polygamy just a sheer lust. Vice Indonesia through its program wanted to lead other women to maintain buman rights and protect women by introducing feminism.
\end{abstract}

Keywords : Framing; Vice Indonesia; Polygamy.

\begin{abstract}
ABSTRAK
Tujuan dari penelitian ini adalah untuk mengetahui bagaimana isu poligami dikemas dalam video Polemik Poligami di Indonesia: Berbagi Surga pada Channel Youtube Vice Indonesia dengan model analisis Zhongdang dan M. Kosicki melalui perangkat sintaksis, perangkat skrip, perangkat tematik, dan perangkat retoris yang disorot dalam bingkai kisah video. Metodologi penelitian ini menggunakan pendekatan kualitatif dengan pengumpulan data melalui dokumentasi pada video, lalu data yang diperoleh kemudian dianalisis melalui struktur framing model Zhongdang dan M. Kosicki. Hasil penelitian menunjukkan bahwa Vice Indonesia membingkai poligami sebagai nafsu semata. Vice Indonesia lewat tayangannya ingin menggiring perempuan-perempuan lain untuk tetap mempertahankan hak-hak asasi manusia dan perlindungan wanita dengan mengenalkan paham feminisme.
\end{abstract}

Kata kunci: Framing; Vice Indonesia; Poligami.

\section{PENDAHULUAN}

Isu poligami merupakan isu yang alot diperbincangkan karena sampai saat ini masih tetap menimbulkan perdebatan. Di Indonesia sendiri, praktik poligami tak sulit ditemui. Berbagai kalangan sudah ada yang melakukannya baik publik figur ataupun masyarakat biasa. Sebagai negara yang didominasi oleh umat beragama islam, poligami menjadi hal yang dibenarkan asal memiliki izin dari isteri. Aturan ini pun diatur sedemikian rupa dalam Undang-undang Perkawinan Nomor 1 Tahun 1974. Hal inilah yang menimbulkan banyak pro dan kontra. Komisioner Komisi Nasional Perempuan, Imam Nahei bahkan sempat membuat pernyataan bahwa poligami adalah bagian dari kekerasan terhadap perempuan, "Komnas Perempuan: Praktik Poligami adalah Kekerasan Terhadap Perempuan". www.voaindonesia.com. (akses 25 Maret 2019).

Lahirnya pro dan kontra di kalangan masyakarat memang tidak dapat dipungkiri. Karena setiap orang berhak memiliki cara pandang yang berbeda terhadap poligami. Dasar kalangan yang pro tehadap fenomena poligami adalah dalam Al-Qur'an pada surah An-Nisa' ayat 3: 


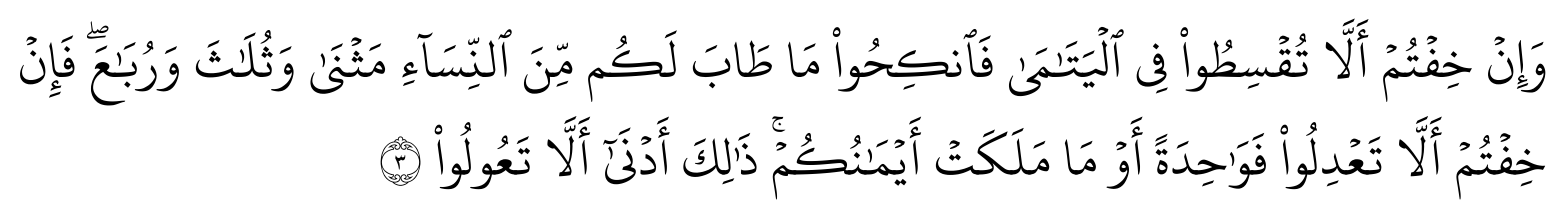

Artinya : Dan jika kamu takut tidak akan dapat berlaku adil terhadap (hak-hak) perempuan yang yatim (bilamana kamu mengawininya), maka kawinilah wanitawanita (lain) yang kamu senangi: dua, tiga atau empat. Kemudian jika kamu takut tidak akan dapat berlaku adil, maka (kawinilah) seorang saja, atau budak-budak yang kamu miliki. Yang demikian itu adalah lebih dekat kepada tidak berbuat aniaya.

Lalu sebagian lagi yang kontra memegang argumen pada surah An-Nisa' ayat 129:

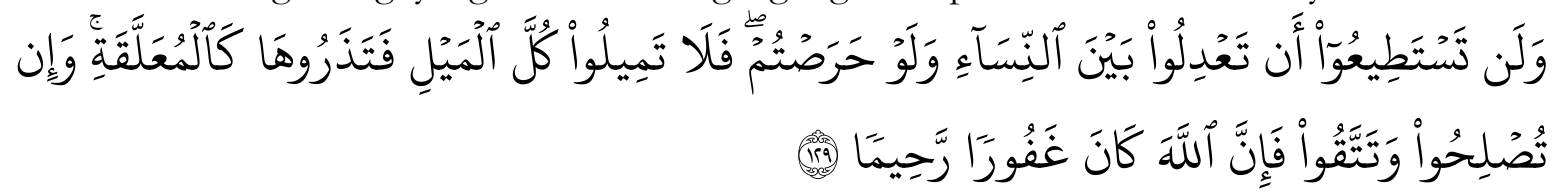

Artinya : Dan kamu sekali-kali tidak akan dapat berlaku adil di antara istri-istri (mu) walaupun kamu sangat ingin berbuat demikian, karena itu janganlah kamu terlalu cenderung (kepada yang kamu cintai), sehingga kamu biarkan yang lain terkatung-katung. Dan jika kamu mengadakan perbaikan dan memelihara diri (dari kecurangan), maka sesungguhnya Allah Maha Pengampun lagi Maha Penyayang.

Dari sudut pandang sejarah islam, kehidupan Rasulullah saw, maka kita dapat mengetahui bahwa nabi juga pernah melakukan poligami bukan serta merta hanya untuk memenuhi hasrat nabi belaka sebab kita mengetahui bahwa nabi dalam hidupnya mengajak pada kebaikan dan menyuruh untuk meninggalkan keburukan di masa jahiliyah, begitu juga perilaku nabi ketika melakukan poligami adalah untuk menjaga hak dan martabat wanita yang dinikahinya. Poligami yang terjadi pada masa rasulullah dengan sekarang jelas berbeda. Pada praktiknya saat ini, poligami dilakukan dengan beragam alasan. Salah satu alasan yang dikemukakan adalah bahwa laki-laki memiliki kemungkinan untuk menyukai lebih dari satu wanita. Alasan ini dikemukakan seorang lelaki yang melakukan poligami direkam dalam sebuah video berdurasi 24 menit. Video ini produksi oleh media Vice Indonesia dengan judul "Polemik Poligami di Indonesia: Berbagi Surga".

Vice Indonesia yang dikenal memiliki gaya jurnalisme mampu bercerita secara mendalam dan berani, mengawali bisnis di Montreal, Canada pada tahun 1994. Dengan pengalamannya berekspansi di lebih dari 25 negara, Vice kini telah membukukan pendanaan total senilai $\$ 770$ juta, "Media Vice Hadir di Indonesia Untuk Ekspansi Pertamanya di Asia Tenggara". www.dailysocial.id (akses 19 Maret 2019). Vice Indonesia memanfaatkan Youtube untuk memproduksi produk jurnalistik. Youtube yang dikenal sebagai media di era mutakhir ini berhasil menyita banyak perhatian khususnya anak muda. Menurut data Badan Pusat Statistik (BPS) per tahun 2015 jumlah penduduk usia muda di Indonesia mencapai 62,4 juta atau setara 25 persen dari total penduduk. Angka ini menjadi target fantastis untuk diupayakan oleh Vice, terlebih kaum millennials di Indonesia tergolong cukup konsumtif dan mengagumi kontenkonten "muda". Maka tidak mengherankan jika video berjudul "Polemik Poligami di Indonesia: Berbagi Surga" telah berhasil mengundang banyak perhatian dengan ditonton sebanyak 1.072.323 kali. Menurut survei yang dilansir oleh CNN Indonesia, jumlah netizen Indonesia yang menonton YouTube hampir menyaingi jumlah netizen yang menonton televisi. Hal ini terungkap dari Survei Google dan Kantar TNS pada Januari 2018. Menurut survei itu, YouTube ditonton oleh 53 persen pengguna internet di Indonesia. Sementara 57 persen 
netizen juga menonton televisi, "Penonton Youtube Saingi Jumlah Netizen Televisi". www.cnnindonesia.com (akses 19 Maret 2019). Dengan demikian, Vice Indonesia memiliki peluang besar untuk menyebarluaskan produk jurnalistik dengan cara pandang mereka.

\section{METODE PENELITIAN}

Penelitian ini menggunakan pendekatan kualitatif, memusatkan perhatian pada prinsip-prinsip umum yang mendasari perwujudan sebuah makna dari gejala-gejala sosial di masyarakat. Objek analisis dalam pendekatan kualitatif adalah makna dari gejala-gejala sosial dan budaya dengan menggunakan kebudayaan dari masyarakat bersangkutan untuk memperoleh gambaran mengenai kategorisasi tertentu (Bungin, 2008). Dan penelitian ini bersifat kualitatif karena dalam pelaksanaannya lebih dilakukan pada pemaknaan teks.

Pendekatan analisis kualitatif menggunakan pendekatan logika induktif, silogismenya dibangun berdasarkan hal khusus atau data di lapangan dan bermuara pada hal-hal umum. Analisis ini tidak digunakan untuk mencari data frekuensi, akan tetapi untuk menganalisis dari data yang tampak, maka analisis ini digunakan untuk memahami fakta dan bukan untuk menjelaskan fakta tersebut. Berdasarkan dari tujuannya ini menggunakan jenis penelitian eksplanatif.

Penelitian eksplanatif bertujuan untuk menjelaskan sebuah permasalahan yang telah memiliki gambaran yang jelas, dan bermaksud menggali secara lebih dalam. Peneliti mencoba mencari tahu sebab dan alasan mengapa peristiwa bisa terjadi, diantaranya menjelaskan secara akurat mengenai satu topik masalah, menghubungkan topik-topik yang berbeda namun memiliki keterkaitan.

Pada penelitian ini peneliti menggunakan dua mcam teknik: Pertama, Studi Kepustakaan (Library Research), penelitian dilakukan dengan cara mengumpulkan semua data yang berasal dari literatur serta bahan bacaan yang relevan dengan penelitian ini. Hal tersebut dilakukan dengan cara membaca buku-buku, literatur, serta tulisan yang berkaitan dengan masalah yang dibahas. Kedua, Studi dokumen (Document Research), penelitian dilakukan dengan cara mengumpulkan data yang dianalisis dari dialog yang terdapat di dalam video. Penulis mencatat keseluruhan dialog dari tiap-tiap narasumber.

\section{HASIL PENELITIAN DAN PEMBAHASAN}

\section{Struktur Sintaksis}

Secara sintaksis, Vice Indonesia mengangkat tentang polemik poligami dari sisi jaminan surga yang dituliskan sebagai headline. Berangkat dari kata "Berbagi Surga" pada headline itu, Vice kemudian menggali lebih dalam lagi fakta seputar poligami dengan mendatangi konferensi poligami untuk melihat langsung kumpulan orang-orang tersebut.

Berlatarkan informasi di konferensi, Vice mengawali alur cerita videonya dengan mendatangi lokasi konferensi di daerah Bekasi, Jawa Barat. Tepat dimana Riski Ramdani, seorang lelaki yang mempunyai dua istri yang juga sekaligus CEO dari Komunitas Poligami ini di temuinya. Selain menjadikan Riski Ramdani sebagai informan, Vice juga menjadikan kedua istrinya sebagai informan, lalu ditambah dengan informan pendukung argumen Vice dengan mewawancarai salah seorang ibu yang meninggalkan poligami dan juga mewawancarai salah seorang akademisi Islam. Kelima informan tersebut diwawancarai Vice dilokasi yang berbeda dan mewawancarai berurut sehingga alur yang dibuat lebih hidup mulai dari mendatangi konferensi, mengunjungi rumah Riski dan rumah istri keduanya, lalu berwisata bersama hingga Vice menemui seorang ibu yang meninggalkan poligami kemudian diakhir menemui akademisi Islam.

Beberapa kutipan sumber pada video "Polemik Poligami di Indonesia: Berbagi Surga" seolah mengkomunikasikan kepada penikmat video bahwa tujuan utama poligami itu untuk 
menyalurkan nafsu. Tercermin dari bagaimana Vice menjadikannya sebagai pembuka video dengan mengutip ucapan dari Riski mengenai nafsu lelaki.

"Allah konflik manusia itu, lelaki itu, untuk mempunyai kemungkinan menyukai lebih dari satu wanita. Nah itu yang terjadi perselingkuhan ada gak?” (Menit ke 4 lewat 8 detik).

"Itu bukti bahwa hakikatnya dorongan-dorongan itu gak bisa dinafikan ada pada lakilaki. Tapi di sisi lain islam memberikan jalan keluar nikah lagi. Menyalurkan nafsu kepada istrinya menjadi ibadah. Yang asalnya Cuma satu ibadah di satu titik menjadi dua titik. .... (Menit ke 4 lewat 28 detik).

Fakta-fakta yang dihimpun Vice dalam video memberikan cerminan perihal poligami semata-mata hanya untuk menyalurkan hawa nafsu. Fakta tersebut juga diperkuat dari ucapan kedua istrinya yang memiliki argumen yang sama dan ditonjolkan di dalam video ini.

“....keinginan dia terus memiliki keinginan yang sama seperti awal menikah.” (Ungkapan istri pertama di menit ke 19 lewat 3 detik).

“...karena hasrat lelaki kan lebih tinggi ya." (Ungkapan istri kedua di menit ke 19 lewat 7 detik).

Kutipan sumber dari informan lainnya seperti ibu yang meninggalkan poligami semakin mempertegas bahwa kontra terhadap poligami itu nyata. Vice memunculkan sosok ibu ini setelah mendapat fakta dari Riski dan kedua istrinya yang mendukung poligami.

"Ibu gak percaya ah, masa kok ibadah harus menyakitkan kita sih. Apakah gak ada ibadah yang lain? Masih banyak jalan menuju roma loh mbak. Emangnya kita masuk surga cuma karena di poligami? Allah maha pengasih maha penyayang masa kita disakiti." (Menit ke 20 lewat 16 detik).

Tidak hanya memunculkan argumentasi yang bertentangan dari ibu yang meninggalkan poligami, Vice kembali memunculkan argumen kontra terhadap poligami lewat seorang akademisi Islam.

"Di dalam surah yang sama, di ayat 129 itu 'engkau tidak akan pernah bisa berbuat adil diantara perempuan walaupun engkau menginginkannya. Poligami itu pasti diharamkan karena dikhawatirkan pasti tidak adanya keadilan." (Menit ke 21 lewat 8 detik).

Vice menutup videonya dengan melemparkan kebingungan karena belum mempunyai kesimpulan pasti. Vice juga memberikan kebebasan pendapat untuk penikmat video namun dengan melempar konflik dan kontra yang mencolok.

“....Di titik ini gue belum punya kesimpulan pasti. Tapi satu yang gue tau, seiring poligami bergerak ke ranah mainstream perdebatan seputar poligami justru akan semakin sengit." (Menit ke 23 lewat 40 detik).

\section{Struktur Skrip}

Analisis skrip dapat dilihat dari unsur $5 \mathrm{~W}+1 \mathrm{H}$ yakni: (What) Problematika Paktik Poligami di Indonesia, (Who) Riski Ramdani, Dwi Rosilawati, Rima Sarah, Penyintas Poligami, Nina Nurmala, (Where) Di Provinsi Jawa Barat di beberapa tempat mulai dari lokasi konferensi Komunitas Poligami di Bekasi, kediaman Riski di Rancaekek, rumah istri kedua Riski di Cibiru, dan wisata ke MT Manglayang, (Why) munculnya pro dan kontra di kalangan masyarakat.

Reporter mendatangi konferensi komunitas poligami di Bekasi, Jawa Barat. Kemudian, reporter mendatangi langsung kediaman Riski Ramdani (CEO Komunitas Poligami) untuk melihat langsung kehidupan keluarga poligami, mewawancarai Riski dan kedua istrinya. Lalu pergi mewawancarai salah seorang perempuan yang dipoligami dan diakhir meminta tanggapan seorang akademisi Islam (How).

Video "Polemik Poligami di Indonesia : Berbagi Surga" belum memenuhi kaidah berita $5 \mathrm{~W}+1 \mathrm{H}$ yang lengkap karena tidak mencantumkan unsur when dalam videonya. Tidak ada waktu persis kapan dilakukan aktivitas di dalam video. 


\section{Struktur Tematik}

Secara tematik, Vice menggunakan lima jenis koherensi dalam menceritakan fakta di dalam video "Polemik Poligami di Indonesia: Berbagi Surga" yaitu, Koherensi Kontras, Koherensi Aditif, Koherensi Kausalitas, Koherensi Perurutan, dan Koherensi Kronologis. Analisis tematik yang paling menonjol di dalam video terlihat jelas melalui perangkat koherensi yang digunakan. Diawal video Vice sudah memunculkan koherensi kontras yang mengekspresikan sikapnya secara implisit.

"Indonesia ada di tengah pertarungan definisi menjadi muslim sejati. Namun, hanya sedikit yang mampu memecah belah umat seperti poligami. $86 \%$ penduduk Indonesia menentang praktik ini." (Koherensi Kontras di detik ke 40 dalam video).

"Memang tujuan gue dari awal melihat langsung bagaimana keluarga poligami. Tapi sejujurnya pengalaman ini membuat gue agak tidak nyaman." (Koherensi Kontras di menit ke 18 lewat 3 detik).

"Setelah bicara dengan salah satu penyintas, sulit untuk tidak setuju dengan perspektifnya. Namun, sulit juga mengabaikan argumen puluhan perempuan lain yang berpartisipasi aktif dalam perjodohan poligami." (Koherensi Kontras di menit ke 23 lewat 25 detik).

"Di titik ini gue belum punya kesimpulan pasti. Tapi satu yang gue tau, seiring poligami bergerak ke ranah mainstream perdebatan seputar poligami justru akan semakin sengit." (Koherensi Kontras di menit ke 23 lewat 39 detik).

Melalui perangkat koherensi membantu melihat bagaimana pemahaman dari Vice yang diwujudkan dalam bentuk yang lebih kecil. Vice juga detail dalam mengemas pesan mana yang dikembangkan dan mana yang diceritakan dengan detail yang besar sehingga terlihat jelas akan gambaran bagaimana wacana yang dikembangkan oleh $V$ ice melalui videonya.

\section{Struktur Retoris}

Fakta yang dimunculkan lewat penggunaan kata "kontroversial" di detik ke 38 diawal video mempresentasikan adanya perdebatan argumen dalam video ini. Leksikon "tabu" dan "mengerikan" pada poligami memberi label bagaimana Vice menggambarkan peristiwa. Dari leksikon yang digunakan itu Vice memposisikan sikap dirinya ke argumen mana ia berada. Beberapa kali juga kata "feminis" muncul di dalam video dari para informan. Kata itu muncul setelah reporter Vice mulai mempertanyakan gender antara perempuan dan laki-laki. Secara implisit menyampaikan ideologi feminisme.

Penggunaan salah satu idiom yaitu "Puncak Keshalehan" yang dilabelkan kepada Riski Ramdani pelaku poligami terkesan melebihkan, padahal tidak ada kutipan dari informan yang menyatakan demikian. Media memang dituntut untuk membuat berita yang nyata, yaitu fakta yang sesungguhnya terjadi di lapangan. Namun, ada kepentingan-kepentingan lain yang pada akhirnya membuat realitas berita berbeda dengan realitas sesungguhnya (Ayu Nur Irwinesia Putri, 2012).

Pemakaian metafora melalui kutipan dari ayat suci alquran yang menganjurkan untuk tidak melakukan poligami ketika tidak adil menjadi penguat makna pesan utama dari Vice yang menentang poligami. Dengan penggunaan metafora ini, khalayak bisa menjadikannya sebagai landasan berpikir atas pendapat atau gagasan yang ingin diputuskan.

Vice juga melengkapi tampilan bagaimana aktivitas Konferensi Komunitas Poligami, kediaman Riski bersama keluarga (istri pertama), kediaman istri kedua, hingga berkunjung ke tempat wisata bersama istri-istri Riski dan anak-anaknya. Tampilan ini menjadi pelengkap peristiwa.

Penekanan argumen dari segi grafis juga tampak dalam penggunaan kutipan "Heaven And Hell (Indonesia's Fight Over Polygamy)" pada video. Vice sudah memunculkan argumennya sejak di bagian awal video. 


\section{Poligami Dalam Bingkai Vice Indonesia}

Vice Indonesia memaknai poligami sebagai suatu topik perbincangan yang kontroversial. Dalam membuat sebuah berita, nilai berita menjadi salah satu kriteria yang sangat diperlukan oleh wartawan atau reporter untuk dapat memutuskan fakta yang pantas dijadikan berita (diangkat) dan memilih mana yang lebih baik. Nilai berita tersebut dinamakan dengan proximity atau kedekatan. Faktor kedekatan memiliki pengaruh pada nilai berita karena wartawan akan mampu melihat masalah secara komprehensif.

Vice tidak mendukung atau menentang praktik tersebut, namun menunjukkan bahwa praktik poligami dipertentangkan. Pihak-pihak yang setuju dan tidak setuju dengan praktik poligami diberi ruang argumentasi yang sama porsinya. Pandangan Vice ini dapat dilihat dari judul "Praktik Poligami di Indonesia: Berbagi Surga". Dalam pandangan Vice, poligami memicu perbedaan pendapat antara yang setuju dan yang tidak setuju.

Dari analisis sintaksis terlihat bagaimana frame disusun dalam skema video yang dibuat. Frame itu tampak jelas dari judul yang dipakai "Praktik Poligami di Indonesia: Berbagi Surga", Vice memakai kata "Berbagi Surga". Pemakaian judul dengan menggunakan kata itu, Vice ingin menekankan bahwa praktik poligami mempertaruhkan segalanya harus dibagi. Lead yang digunakan pada pembuka video Vice juga menunjukkan secara jelas bagaimana frame dari Vice. Lead memberikan sudut pandang tersendiri dari video yang ditampilkan dengan cara memberikan pernyataan secara langsung mengenai tema yakni menyatakan poligami sebagai topik perbincangan yang kontroversial.

Lead video Vice secara jelas menunjukkan bahwa pro-kontra poligami terjadi di masyarakat. Pandangan setuju dan tidak setujunya terhadap poligami disajikan dengan skema tertentu dalam narasi. Fakta-fakta disusun dengan cara memisahkan pendapat yang setuju dan pendapat yang tidak setuju. Pada video yang ditampilkan, teknik penyusunan fakta secara perlahan memberi penekanan yang lebih atas pendapat seseorang (kontra) dan mengecilkan pendapat yang lain (pro). Ada fakta-fakta yang diangkat menjadi berita, ada juga yang tidak. Ada yang dominan ditonjolkan dan ada yang tidak. Hal ini dapat dilihat dari siapa narasumber yang ditanyai, isu-isu apa yang dominan diangkat dari video yang ditampilkan.

Frame yang digunakan Vice juga dapat diamati dengan melihat bagaimana Vice mengisahkan praktik poligami tersebut ke dalam sebuah video. Dari keseluruhan unsur berita $5 \mathrm{~W}+1 \mathrm{H}$, unsur (why) lebih terlihat dalam video. Melalui unsur (why), pendapat Riski Ramdani secara jelas bertolak belakang dengan pendapat akademisi, begitu juga pendapat istri Riski yang berbeda dengan pendapat seorang penyintas. Melalui cara ini, Vice ingin memperlihatkan pendapat mana yang lebih ditonjolkan. Karena dengan cara inilah khalayak seringkali terpengaruh oleh sisi-sisi yang ditonjolkan atau ditekankan oleh media dan mungkin sedikit mengabaikan atau mengesampingkan beberapa fakta ... (Nani Kurniasari, Gilang Gusti Aji, 2015).

Struktur tematik memperlihatkan, Vice membawa dua tema besar yang ingin ditampilkan kepada khalayak. Pertama, praktik poligami yang dilakukan di Indonesia menimbulkan pro dan kontra. Pro dan kontra ditampilkan dengan cara menampilkan pendapat yang berseberangan. Di satu sisi pendapat yang mendukung poligami meninjau dari sisi solusi mengatasi nafsu lelaki dan satu sisi pendapat yang menentang poligami diakui secara terang-terangan menyakiti hati perempuan. Pendapat ini dimunculkan dari Riski Ramdani, lelaki yang melakukan poligami yang pendapatnya bertentangan dengan pendapat seorang akademisi islam.

Melalui kapasitas dan kompetensinya untuk membuat, menggerakkan, atau bahkan membalikkan opini publik, media massa bisa menjadi penentu. Dalam memberitakan sebuah peristiwa, media massa tidak berdiri bebas dari kepentingan. Media massa bukanlah sekedar saluran yang menyajikan informasi kepada khalayak tentang peristiwa yang terjadi secara apa adanya, melainkan media massa terikat dengan ideologi yang dianut oleh pemiliknya. Alhasil, segala sesuatu yang diproduksi dan disajikan oleh media massa adalah hasil representasi 
ideologi pemiliknya, (Michelle Noor Azzaro, 2018).

Tema kedua dalam video ini yaitu paham feminisme yang ingin dikenalkan sebagai bentuk dukungan terhadap perempuan dengan mengatasnamakan keadilan. Tema ini ditampilkan dengan menyajikan pandangan seorang reporter melalui pertanyaan yang diajukan kepada Riski Ramdani sebagai pelaku poligami. Reporter mengajukan pertanyaan bahwa apakah secara tidak langsung poligami dianggap sebagai kekerasan terhadap wanita karena menyakiti perasaan mereka.

Selain ditampilkan melalui pertanyaan yang diajukan reporter, argumen dari reporter juga dapat diamati sebagai perwakilan tema kedua ini. Pernyataan reporter diucap saat dirinya hadir pada konferensi poligami yang menyatakan bahwa jika dia dibolehkan memiliki suami dua, dia akan menghiraukannya. Argumentasi yang dilontarkan lewat kalimat "Kalo gue boleh punya suami dua" dari seorang reporter memberi sinyal penyamaan peran antara laki-laki dan perempuan.

Pada praktik poligami, Vice melalui videonya membingkai poligami sebagai bentuk yang tidak adil, menguntungkan sepenuhnya pihak lelaki dan merugikan perempuan. Fakta-fakta ditampilkan dengan memberi ruang penyintas untuk bersuara mengenai penolakannya terhadap poligami karena tersakiti sebagai perempuan. Melalui fakta yang ditampilkan ini, Vice secara perlahan mulai mencerminkan ideologinya. Pemilihan fakta yang terjadi di lapangan yang kemudian dikemas oleh media memiliki alasan kepentingan politik dan ideologi tersendiri bagi media (Ardhina Pratiwi, 2018).

Strategi redaksi media yang dilakukan dalam menentukan isi media menurut Pamela J. Shoemaker dan Stephen D. Reese (1996) terdapat lima level yang memengaruhinya yaitu individu, rutinitas media, organisasi, ekstra media, dan ideologi. Melalui video ini, level kelima menjadi faktor terbesar yang memengaruhi isi video. Vice Indonesia yang merupakan media asal luar negeri memiliki ideologi yang berbeda.

Video Vice Indonesia membingkai realitas untuk disajikan kepada khalayak dengan strategi konstruksi terkait poligami diproses melalui video narasi lengkap dihubungkan dengan konvensinya. Video "Polemik Poligami di Indonesia: Berbagi Surga" dikemas dengan menyampaikan pesan bahwa poligami masih terus dipertentangkan dan memberi dampak yang merugikan perempuan. Vice secara implisit melalui videonya juga menggiring khalayak untuk membuka mata perempuan tentang feminisme yang tentu menolak secara terang-terangan praktik poligami karena dianggap sebagai bentuk ketidakadilan terhadap perempuan.

\section{PENUTUP}

Vice Indonesia membingkai video "Polemik Poligami di Indonesia: Berbagi Surga" bahwa poligami terjadi dominan hanya karena nafsu semata. Vice Indonesia lewat tayangannya ingin menggiring perempuan-perempuan lain untuk tetap mempertahankan hak-hak asasi manusia dan perlindungan perempuan. Mengenalkan paham feminisme dengan mengatasnamakan keadilan. Vice Indonesia lewat tayangannya mengajak khalayak untuk sama-sama berpikir bahwa poligami adalah salah satu ajaran islam yang masih dipertentangkan praktiknya.

\section{DAFTAR PUSTAKA}

Alkat, R. (2014). Analisis Framing Pemberitaan Pemiliban Gubernur Kalimantan Timur 2013 Pada Masa Kampanye. Vol 2 (No. 4): 4-5.

Ardiyanto, E. \& Q-Annes. (2007). Filsafat Ilmu Komunikasi. Bandung: Simbiosa Rekatama Media.

Ayuwuragil, K. (2019, Maret 19). Media Vice Hadir di Indonesia Untuk Ekspansi Pertamanya di Asia Tenggara. Dikutip dari www.dailysocial.id. 
Bungin, \& Burhan. (2008). Sosiologi Komunikasi: Teori, Paradigma dan Diskursus Teknologi Komunikasi di Masyarakat. Jakarta: Kencana.

Dwi Anggoro, Ayub. (2014). Media, Politik, dan Kekuasaan. Vol 2 (No.2): 28-29.

Effendy, \& Uchjana, O. (2004). Ilmu Komunikasi Teori dan Praktek. Bandung: PT. Remaja Rosdakarya.

Eka, R. (2019, Maret 19). Penonton Youtube Saingi Jumlah Netizen Televisi. Dikutip dari www.cnnindonesia.com.

Eriyanto. (2015). Analisis Framing: Konstruksi, Ideologi dan Politik Media. Yogyakarta: LkiS Yogyakarta.

Gusti, S. \& Rizka. (2018). Analisis Framing Pemberitaan Medan Kota Terbaik 2017 di Surat Kabar Harian Analisa. Skripsi S1. Medan: Univeristas Sumatera Utara.

Hartanti, Y. (2007). Kohesi dan Koherensi Dalam Wacana Pada Buku Teks Bahasa dan Sastra Indonesia untuk SMA Kelas X Karangan Dawud, dke. Program Studi Bahasa dan Sastra Indonesia, FBS Universitas Negeri Yogyakarta. Yogyakarta: Terbitan Erlangga.

Kolin, G. (2018). Analisis Framing Zhongdang Pan dan Gerald M. Kosicki Tentang Pemberitaan PKI di Majalah Lentera Nomor 3/2015 Edisi Salatiga Kota Merah. Skripsi S1. Medan: Universitas Sumatera Utara.

Kriyantono, R. (2008). Teknis Praktis Riset Komunikasi. Jakarta: Kencana.

Kurniasari, N. \& Gusti, A.G. (2015). Kepemilikan dan Bingkai Media. Vol. 6 (No. 1): 99.

Kusumaningrat, H. (2006). Jurnalistik Teori dan Praktek. Bandung: PT. Remaja Rosdakarya.

Masyarrofah, U \& dkk. (2017). Analisis Framing Tentang Poligami Dalam Film Surga Yang Tak. Dirindukan. Vol 13 (No. 1): 62-64.

McQuail, D. (2012). Teori Komunikasi Massa. Jakarta: Salemba.

Mulyana, D. (2006). Metodologi Penelitian Kualitatif: Paradigma Baru Ilmu Komunikasi dan Ilmu Sosial Lainnya. Yogyakarta: Pustaka Pelajar.

Mustika, R. (2017). Analisis Framing Pemberitaan Media Online Mengenai Kasus Pedofilia di Akun Facebook. Vol 2 (No.2): 138-139.

Nawawi, H. (2001). Metode Penelitian Sosial. Yogyakarta : UGM Press.

Azzaro, M.N. (2018). Analisis Framing Pemberitaan Pembubaran Hiøbut Tabrir Indonesia. Vol 1 (No. 1): 2.

Nur Irwinesia Putri, Ayu. (2012). Analisis Framing Berita Demonstrasi Mahasiswa Semarang Terkait Kenaikan Harga BBM Pada TV Borobudur. Vol 4 (No. 1) : 19-20.

Nurudin. (2004). Komunikasi Massa. Malang: Cespur.

Pratiwi, A. (2018). Konstruksi Realitas dan Media Massa. Vol 19 (No.1): 54.

Setiawan, R. (2013). Kekuatan New Media Dalam Membentuk Budaya Populer di Indonesia. Vol 1 (No.2): 359-360.

Shoemaker, P. J. \& Stephen D. R. (1996). Mediating TheMessages: Theories of Influences on Mass Media Content. Second edition. USA: Logman Publisher.

Sobur, A. (2009). Analisis Teks Media: Suatu Pengantar untuk Analisis Wacana, Analisis Semiotika dan Analisis Framing. Bandung: PT. Remaja Rosdakarya. 
Soemirat, S. \& Elvinaro, A. (2007). Dasar-Dasar Public Relations. Bandung: $\quad$ PT. Remaja Rosdakarya.

Suyono. (2007). Cerdas Berpikir Bahasa dan Sastra Indonesia. Jakarta: Ganeca Exact.

Syaifullah, A. (2017). Isu Poligami Dalam Film Surga Yang Tak Dirindukan (Analisis Framing Robert N. Entman). Vol 4 (No. 2): 8-9.

Wardah, F. (2019, Maret 25). Komnas Perempuan: Praktik Poligami adalah Kekerasan Terbadap Perempuan. Didapat dari www.voaindonesia.com.

Wihayati, A. (2018). Analisis Framing Pandanga Poligami Dalam Acara Cerita Hati Kompas TV Episode 183. Skripsi S1. Surabaya: Universitas Islam Negeri Sunan Ampel. 